\title{
IMPROVE THE FIRST-YEAR STUDENTS' ENGLISH SPEAKING PERFORMANCE AT THAI NGUYEN UNIVERSITY OF AGRICULTURE AND FORESTRY THROUGH LANGUAGE GAMES
}

\author{
Nguyen Lan Huong*, Van Thi Quynh Hoa \\ TNU University of Agriculture and Forestry
}

\begin{abstract}
Speaking seems to be the most important skills of all the four skills (listening, speaking, reading and writing). Nowadays, it is not easy for learners to speak English well, so the purpose of this study was to find out the effectiveness of using language games to improve the first - year students' speaking performance at Thai Nguyen University of Agriculture and Forestry (TUAF). The quasi-experimental design was used in the study, using questionnaire, pre-test and post-test as the main data collection instruments. The subjects of the study were sixty first-year students at TUAF. The results of the study showed that there is no significant difference between the mean pre-test scores of the experimental and control group. But there is significant difference between the mean post-test scores of the experimental and the control group. Based on the research findings, some recommendations were made. The current study was expected to help first-year students improve their performance in speaking classes.
\end{abstract}

Key words: speaking performance; English language; first-year; language; language games

Received: 29/3/2019; Revised: 23/5/2019; Approved: 29/5/2019

\section{SỬ DUUNG TRÒ CHƠI NGÔN NGŨ ĐỂ NÂNG CAO KHẢ NĂNG NÓI TIẾNG ANH CỦA SINH VIÊN NĂM THỨ NHẤT TRƯờnG ĐẠI HỌC NÔNG LÂM - ĐẠI HỌC THÁI NGUYÊN}

\author{
Nguyễn Lan Hương*", Văn Thị Quỳnh Hoa \\ Truòng Đại học Nông Lâm - ĐH Thái Nguyên
}

\section{TÓM TẮT}

Kĩ năng nói thường được coi là một trong những kĩ năng khó nhất của việc học ngôn ngữ. Thật không dễ dàng để người học ngoại ngữ có thể nói tốt vì vậy mục đích của nghiên cứu này là để tìm ra hiệu quả của việc sử dụng trò chơi ngôn ngữ để nâng cao khả năng nói tiếng Anh của sinh viên năm thứ nhất tại trường Đại học Nông Lâm - Đại học Thái Nguyên. Đối tượng nghiên cứu là 60 sinh viên thuộc trường Đại học Nông Lâm. Nghiên cứu sử dụng phương pháp thực nghiệm, câu hỏi điều tra, bài kiểm tra trước và bài kiểm tra sau là công cụ chính để thu thập dữ liệu. Kết quả cho thấy không có sự khác biệt giữa điểm số trung bình của sinh viên của 2 nhóm trong bài kiểm tra trước khi bắt đầu khoá học. Kết quả của bài kiểm tra cuối khoá học chứng minh rằng sinh viên của nhóm sử dụng trò chơi ngôn ngữ trong học kĩ năng nói có điểm số cao hơn những sinh viên ở nhóm giảng dạy theo phương pháp truyền thống. Dựa trên kết quả nghiên cứu, tác giả đã đưa ra một số kiến nghị và tác giả cũng hi vọng rằng nghiên cứu này sẽ giúp sinh viên năm thứ nhất trường Đại học Nông Lâm - Đại học Thái Nguyên nâng cao khả năng nói tiếng Anh.

Từ khóa: khả năng nói; tiếng Anh; năm thứ nhất; ngôn ngũu; trò choi ngôn ngũu

Ngày nhận bài: 29/3/2019; Ngày hoàn thiện: 23/5/2019; Ngày duyệt đăng: 29/5/2019

\footnotetext{
* Corresponding author. Email: nguyenlanhuong@tuaf.edu.vn

DOI: $\underline{\text { https://doi.org/10.34238/tnu-jst.2019.06.445 }}$
} 


\section{Introduction}

Speaking is a crucial part of second language learning and teaching. Despite its importance, for many years, teaching speaking has been undervalued and English language teachers have continued to teach speaking just as a repetition of drills or memorization of dialogues. However, today's world requires that the goal of teaching speaking should improve students' communicative skills because students can express themselves and learn how to follow the social and cultural rules appropriate in each communicative circumstance [1]. Nowadays, in order to teach English speaking effectively, teachers have applied communicative language teaching (CLT). It is an approach that helps students be more active in real life situation through the means of individual, pair and group work activities. It encourages students to practice the language they learn in meaningful way. In a CLT classroom, playing games is one activity, which requires students to actively communicate with classmates, using their own language. With the use of games, the teacher can create various contexts in which students have to use the language to communicate, exchange information and express their own opinions.

Games are found out to be an effective technique to teach English because they can incorporate reading, listening and speaking. It gives students a chance to get out of their seats and learn in a hands-on environment. Though games can be effective for all ages, it seems that English games are most effective for elementary to middle-school-aged children, because at this age, they do not think it is childish to play games.

Games in the language classroom can help to involve learners actively in the learning process, provide a challenge which encourages learners to stretch themselves, help learners to forget they are studying: they lose themselves in the fun of the game and the activity motivates them, encourage collaborative learning, provide variety of pace, give extra practice without inducing boredom [2].

Using games, the students became more interested, actively involved and motivated in the learning activities. Games also help the students in building a good relationship with their friends as well as increasing their achievement in learning English [3]. Games can be a very useful teaching technique for the effective and joyful learning. Games are also believed to give the positive effect on the students' interest and motivation in studying English as well as to increase their speaking ability. Games are viable method to achieve many educational objectives such as reinforcement, review, reward, relax, inhibition, reduction, attentiveness, retention and motivation [4]. The value of language games lies not only in the great number of games that have been invented or in the variety of levels they serve but in the useful and purposeful language practice they provide. That is why teachers should make optimal use of games in their language teaching to increase students' work and motivation and to offer them meaningful practice. Provided that teachers can select or design and organize good games in terms of language and type of participation, they will achieve these worthy aims. This study therefore was conducted to find out the effectiveness of using language games in developing speaking skills for first-year students at Thai Nguyen University of Agriculture and Forestry (TUAF).

\section{Subjects and research methodology}

This study utilizes the quasi experimental design. Two groups composed of 60 students were used as the respondents of this study. They were purposively selected based on their mental ability, age and gender. They are divided into two groups: experimental and control groups of 30 students each. The 
control group was taught with traditional method while the experimental group was given lessons using language games approach. The two groups were evaluated at the beginning (pre-test) and at the end (posttest) of the lessons to find out the significant difference of two methods on the achievements of the students. The difference between the mean score of the two groups was then computed and tested for significance.

The data collection instruments of this study were questionnaires and observation. During the process of working on the research, the researchers spent time on observing the students' attitudes towards learning. The questionnaires were designed for distribution to students for the research. In combination with the ones mentioned above, the pre-test and post- tests were administered to measure the ability of the students before and after the lessons. Tests are categorized into five areas: grammar, vocabulary, intonation, stress as well as pronunciation.

\section{Legend:}

$\begin{array}{cl}\text { Marks } & \text { Description (VI) } \\ 9-10 & \text { Excellent } \\ 7-8 & \text { Good } \\ 5-6 & \text { Fair } \\ 1-4 & \text { Poor }\end{array}$

\section{Findings and discussion}

\subsection{Mean performance in pre-test \& post- test mean scores of the control and the experimental groups}

As shown in table 1, the pre-test mean scores of $1.43, \mathrm{SD}=0.41$ and $1.30, \mathrm{SD}=0.45$, indicates that the grammar and pronunciation with verbal interpretation of good, while the pre- test mean scores of $1.06, \mathrm{SD}=0.40,0.82$, $\mathrm{SD}=0.28$ and $0.89, \mathrm{SD}=0.25$, reveals that the vocabulary, intonation and stress has rated as fair. The mean post-test scores of 1.65 , $\mathrm{SD}=0.31$ and $1.55, \mathrm{SD}=0.40$ reveals that the grammar and pronunciation was rated as excellent and the post-test mean score of 1.42 , $\mathrm{SD}=.35$ respectively was "good".

With regard to the control group, pre-test and post-test it revealed that the mean scores of 1.3, $\mathrm{SD}=0.35$ and $1.16, \quad \mathrm{SD}=0.34$ respectively was "good" while the mean scores of $1.35, \mathrm{SD}=0.28, .75, \mathrm{SD}=0.21$ and $0.81, \mathrm{SD}=0.24, \quad .36$ was rated as "fair" while the post-test, the mean of $1.38, \mathrm{SD}=$ $0.39, \quad-1.27, \quad \mathrm{SD}=0.37,1.06, \quad \mathrm{SD}=0.27$ respectively as good and the mean of 0.97 , $\mathrm{SD}=0.21$ rated as the stress as "fair".

The average mean of $1.098, \mathrm{SD}=0.35$ and $1.4, \mathrm{SD}=0.35$ reveals that the mean performance in the pre-test and the post-test mean scores of the experimental group was good while the average are $0.944, \mathrm{SD}=0.284$ and $1.24, \mathrm{SD}=0.294$ reveals that the pre-test and the post-test mean scores was good.

Table 1. Mean Performance in the Pre-test and Post-test of the Experimental and Control Groups

\begin{tabular}{|c|c|c|c|c|c|c|c|c|c|c|c|c|}
\hline \multirow{3}{*}{ Speaking Skills } & \multicolumn{6}{|c|}{ Experimental Group } & \multicolumn{6}{|c|}{ Control Group } \\
\hline & \multicolumn{3}{|c|}{ Pre-test } & \multicolumn{3}{|c|}{ Post-test } & \multicolumn{3}{|c|}{ Pre-test } & \multicolumn{3}{|c|}{ Post-test } \\
\hline & $\mathbf{X}$ & SD & VI & $\mathbf{X}$ & SD & VI & $\mathbf{X}$ & SD & VI & $\mathbf{X}$ & SD & VI \\
\hline Grammar & 1.43 & 0.41 & $\mathrm{G}$ & 1.65 & 0.31 & $\mathrm{E}$ & 1.3 & 0.35 & $\mathrm{G}$ & 1.52 & 0.36 & $\mathrm{E}$ \\
\hline Pronunciation & 1.30 & 0.45 & $\mathrm{G}$ & 1.55 & 0.40 & $\mathrm{E}$ & 1.16 & 0.34 & $\mathrm{G}$ & 1.38 & 0.39 & $\mathrm{G}$ \\
\hline Vocabulary & 1.06 & 0.40 & $\mathrm{~F}$ & 1.42 & 0.35 & G & 0.95 & 0.28 & $\mathrm{~F}$ & 1.27 & 0.32 & G \\
\hline Intonation & 0.82 & 0.28 & $\mathrm{~F}$ & 1.20 & 0.35 & G & 0.75 & 0.21 & $\mathrm{~F}$ & 1.06 & 0.27 & $\mathrm{G}$ \\
\hline Stress & 0.89 & 0.25 & $\mathrm{~F}$ & 1.18 & 0.34 & G & 0.81 & 0.24 & $\mathrm{~F}$ & 0.97 & 0.21 & $\mathrm{~F}$ \\
\hline Average $\bar{X}$ & 1.098 & 0.35 & $\mathrm{~F}$ & 1.4 & 0.35 & G & 0.944 & 0.284 & G & 1.24 & 0.294 & $\mathrm{G}$ \\
\hline
\end{tabular}


Legend:

$\begin{array}{lc}\text { Mark } & \text { Description } \\ 2.0 & \text { Excellent } \\ 1.5 & \text { Good } \\ 1.0 & \text { Fair } \\ 0.5 \text { and below } & \text { Fair }\end{array}$

\subsection{Significance of the Difference in the Performance on the Pre-test}

Table 2. Test of difference between the Mean of Pre-test Scores of the Language Games and the Control Group

\begin{tabular}{ccccccc}
\hline Group & Mean & Var & Df & Q- stat & P-Value & VI \\
\hline Experimental & 1.10 & 0.07 & & 0.41 & 0.54 & \multirow{2}{*}{ Not Significant } \\
\hline Controlled & 1.002 & 0.05 & & & & \\
\hline \multicolumn{5}{c}{$p>$ >.05-not significant } & & \multicolumn{2}{c}{05 -significant }
\end{tabular}

Table 2 reveals the result of the one-way analysis of variance rendered to test the significance of the difference in the subjects' performance on the pre-test.

Results obtained show a computed t- value of 0.41 and a p-value of 0.54 which is greater than $\alpha=$ 0.05 which led to the acceptance of the null hypothesis that there is no significant difference in the subjects' performance on the pre-test. This implies that as far as the pre-test results are concerned, there is no marked difference in the performance exhibited by the experimental and controlled groups.

\subsection{Significance of the Difference between the Mean Post-test Scores of the Language Games (experimental) and Control Group}

Table 3. Significant Difference between the mean Post test scores of the Experimental and Control group

\begin{tabular}{cccccc}
\hline Group & Mean & Mean diff & t-value & P-Value & VI \\
\hline Experimental & 7 & 8 & 2.08898 & 0.47 & Significant \\
\hline Controlled & 6.2 & $p>.05$-not significant & $p^{<.05-\text { significant }}$ &
\end{tabular}

It can be seen from the table that the experimental and the control group have a mean score of 7 and 6.2 with a mean difference of .8. the computed t- value of 2.08898 had $\mathrm{p}$ - value $=0.47$ which is significant at .05 alpha level of significance

The computed t- value of 2.08 and $p$-value of .047 which is less than $\alpha=0.05$ led to the acceptance of the null hypothesis that there is a significant difference in the subjects' performance on the post -test. This implies that as far as the post-test results are concerned, there is marked difference in the performance exhibited by the experimental and controlled group. It implies that the language game approach is better than the traditional approach in developing the speaking skills of the students.

\section{Conclusion and recommendations}

The results of the study indicate that the mean performance in the pre-test and post-test scores of both experimental and control group were "good". There is no significant difference between the mean pre-test scores of the experimental and control group. But there is significant difference between the mean post-test scores of the experimental and the control group.

Based on the results of the study, some recommendations are suggested. Firstly, the perceptions of the two groups of subjects did 
not differ significantly on the speaking lessons given them. Studies of this kind in the future are encouraged to exhaust the possibility of utilizing a syndicated instrument if there is any or to make use of standardized forms. Secondly, the performance of the two groups of subjects did not differ significantly for both the pre-test and the post-test. This may be due to the fact that the approach was used only in the motivational strategy. Results would have been different if the lessons were designed to be totally different in a way that the experimental approach was used in all parts of the lesson and not just in a single phase. Studies of this kind are encouraged to take up this limitation in order to improve the results. Finally, more researches on using language games should be conducted to teach four skills (listening, speaking, reading and writing).

\section{REFERENCES}

[1]. Hayriye Kayi, "Activities to Promote Speaking in a Second Language", the Internet TESL Journal, Vol. XII, No. 11, November 2006.

[2]. Clare Lavery, Language Assistant, British Council ELT, 2001.

[3]. Hoang Tat Truong, Basic English lexicology, National University Publisher, Viet Nam, $2^{\text {nd }}$ ed., 2000.

[4]. Wright, Andrew et al., Games for Language Learning, Cambridge University Press, 4th, 2004. 
